\title{
Correction to: When You Open Your Legs, You Eat: The Discourse of Transactional Sex Among Female Youth in Nigeria
}

\section{Eyo Offiong Mensah ${ }^{1}$}

Published online: 27 September 2019

(C) Springer Science+Business Media, LLC, part of Springer Nature 2019

\section{Correction to: Sexuality \& Culture https://doi.org/10.1007/s12119-019-09648-w}

The original version of the article contains mistakes in the text. The corrected details are provided below.

\section{Transactional Sex, Power and Sexuality}

\section{Para 1, 8th sentence,}

In Nigerian Pidgin, prostitution is called Ashawo, or descried as Money for hand...back for ground (Money in the hand... back on the ground) emphasising a contractual buying and selling of sex.

Should read:

In Nigerian Pidgin, a prostitute is called Ashawo, or described as Money for hand...back for ground (Money in the hand... back on the ground) emphasising a contractual buying and selling of sex.

In para 2, 6th sentence, which previously read:

They are depicted as objects of sexual desire and pleasure. Mensah and Nkamigbo (2016) sustains this claim by stating that in Nigeria, traditional male dominance, power, status and privilege inform an ideal male-female romantic relationship which makes the man the subject and the woman his object of sexual pleasure.

Should read:

They are depicted as objects of sexual desire and pleasure. Mensah and Nkamigbo (2016) sustain this claim by stating that in Nigeria, traditional male dominance,

The original article can be found online at https://doi.org/10.1007/s12119-019-09648-w.

Eyo Offiong Mensah

eyomensah2004@yahoo.com

1 University of Calabar, Calabar, Nigeria 
power, status and privilege inform an ideal male-female romantic relationship which makes the man the subject and the woman his object of sexual pleasure.

\section{Slanguage in Transactional Sex Practices}

In para 5, 6th sentence, which previously read:

On the part of the clients, there are also slang and metaphors they used in labelling patrons and their activities. A frog is a fat patron and a lizard is a thin.

Should read:

On the part of the clients, there are also slang and metaphors they used in labelling patrons and their activities. A frog is a fat patron and a lizard is a thin one.

\section{Conclusion}

In para 1,13 th sentence, which previously read:

These practitioners tend to equate their roles with those of their male partners and adopt choices that are compatible with their desires (Mensah 2018).

Should read:

This category of practitioners tend to equate their roles with those of their male partners and adopt choices that are compatible with their desires (Mensah et al. 2018).

Publisher's Note Springer Nature remains neutral with regard to jurisdictional claims in published maps and institutional affiliations. 